\title{
Allergic Conjunctivitis
}

\section{Vally,* MOE Irhuma}

Division of Clinical and Experimental Pharmacology, Department of Pharmacy and Pharmacology, School of Therapeutic Sciences Faculty of Health Sciences, University of Witwatersrand, Johannesburg

*Corresponding author, email: muhammed.vally@wits.ac.za

\begin{abstract}
Allergic conjunctivitis is a condition characterized by conjunctival inflammation caused by airborne allergens. The symptoms include: itching, excessive lacrimation, discharge, and conjunctival hyperaemia (pink eye). The disease usually affects young adults and is associated with other allergic conditions like allergic rhinitis, and bronchial asthma for example. There are three types of allergic conjunctivitis, namely acute allergic conjunctivitis, seasonal allergic conjunctivitis (SAC) and perennial allergic conjunctivitis (PAC). The diagnosis is primarily clinical and the prevalence is on the increase. Therapeutic modalities include a combination of topical vasoconstrictor and antihistamine therapies, topical antihistamines with mast cell stabilising properties, topical mast cell stabilisers, topical glucocorticosteroids and (in some cases) oral antihistamines when necessary.
\end{abstract}

Keywords: conjunctivitis, allergic conjunctivitis, seasonal allergic conjunctivitis (SAC), perennial allergic conjunctivitis (PAC)

\section{Definition and Introduction}

Allergic conjunctivitis is a condition characterized by conjunctival inflammation, presenting as acute, intermittent or chronic. ${ }^{1}$ It results from an airborne allergen and the symptoms of the condition include itching, excessive lacrimation, ophthalmic discharge, and conjunctival hyperaemia (pink eye). The diagnosis of this condition is primarily clinical and the management is usually through topical antihistamine and mast cell stabilizers. ${ }^{1}$ Allergic conjunctivitis is estimated to affect at least 20 percent of the population (in the United States) on an annual basis with the incidence increasing..$^{2-5}$ It is primarily a condition of young adults with an average age of onset of 20 years and the symptoms of the condition tend to decrease with age. ${ }^{2-5}$ Allergic conjunctivitis has been affiliated with other allergic diseases like allergic rhinitis, bronchial asthma, atopic dermatitis and other related comorbidities. $^{6}$

\section{Pathophysiology}

Allergic conjunctivitis results from contact of an allergen or allergens with the surface of the eye in a person who is allergic to that specific allergen. ${ }^{1,7}$ Both histamine 1 and 2 receptors play a role in ocular allergy. ${ }^{7}$ It is considered a classic type 1 Immunoglobulin E (IgE)-mediated hypersensitivity reaction, and shares a similar pathophysiology to other atopic diseases. ${ }^{7,8}$ Analyses of conjunctival scrapings have shown two phases of this allergic response which are similar to the early and late phases of cutaneous, nasal, and pulmonary allergen responses. ${ }^{7}$
The immediate response to allergens is mediated almost primarily by mast cells, which are present in high concentrations in the conjunctival epithelium and increase further in patients with allergic conjunctivitis. ${ }^{7}$ The mast cells become activated and release histamine via exocytosis. Histamine is the main mediator of this response and causes vasodilatation, vasopermeability, and itching. ${ }^{7}$ Elevated levels have been found in patients with seasonal allergic conjunctivitis. ${ }^{8}$

The late phase response to allergens begins with an influx of other inflammatory cells attracted by cytokines and chemokines released by the mast cells in the immediate phase. Within 6 to 10 hours after allergen challenge, eosinophils, basophils and neutrophils appear. ${ }^{9-13}$ This is followed by lymphocytes and monocytes.9-13 The eosinophils produce and release leukotriene $\mathrm{C}_{4}$, eosinophil peroxidase, eosinophil cationic proteins and histamine into the tear fluid. ${ }^{9}$ These cells create continued inflammation. The presence of eosinophils have been demonstrated in up to 80 percent of conjunctival scrapings in patients with acute allergic conjunctivitis. ${ }^{14}$

\section{Types of Allergic Conjunctivitis}

There are three different types of allergic conjunctivitis, namely: acute allergic conjunctivitis, ${ }^{15,16}$ seasonal allergic conjunctivitis $(\mathrm{SAC})^{1,6}$ and perennial allergic conjunctivitis (PAC). ${ }^{1} \quad$ Table 1 demonstrates the key differences between these types. 
Table 1: Key differences between the three types of allergic conjunctivitis ${ }^{1,6,15-17}$

\begin{tabular}{|c|c|c|}
\hline Acute Allergic Conjunctivitis & Seasonal Allergic Conjunctivitis & Perennial Allergic Conjunctivitis \\
\hline $\begin{array}{l}\text { 1. Sudden onset hypersensitivity reaction that } \\
\text { develops rapidly (within } 30 \text { mins) } \\
\text { 2. Caused by isolated environmental exposure } \\
\text { 3. Resolves promptly when the allergen is } \\
\text { removed (usually within } 24 \text { hrs) } \\
\text { 4. Characterized by intense episodes of: } \\
\text { a. Itching } \\
\text { b. Hyperaemia } \\
\text { c. Tearing } \\
\text { d. Chemosis } \\
\text { e. Eyelid oedema }\end{array}$ & $\begin{array}{l}\text { 1. Progressive onset reaction (compared to } \\
\text { acute allergic conjunctivitis) and occurs } \\
\text { gradually (over days to weeks) } \\
\text { 2. Usually corresponds to a specific pollen } \\
\text { season } \\
\text { 3. Seasonal allergens include: } \\
\text { a. Tree pollen in spring } \\
\text { b. Grass pollen in summer } \\
\text { c. Wood pollen in late summer or autumn }\end{array}$ & $\begin{array}{l}\text { 1. PAC is mild, chronic and has a waxing and } \\
\text { waning quality. } \\
\text { 2. It is related to year round environment } \\
\text { exposure. } \\
\text { 3. PAC allergens include: } \\
\text { a. Dust mites } \\
\text { b. Animal dander } \\
\text { c. Moulds }\end{array}$ \\
\hline
\end{tabular}

Table 2: Clinical presentation of allergic conjunctitivis ${ }^{1,17-20}$

\begin{tabular}{|c|c|c|}
\hline Symptoms & Clinical History & Physical Examination Findings \\
\hline $\begin{array}{l}\text { - Ocular pruritus } \\
\text { - Burning sensation in the eye } \\
\text { - Redness is universal } \\
\text { - Eyelid oedema is common } \\
\text { - Usually bilateral, but one eye can be more } \\
\text { affected than another } \\
\text { - Discharge: watery and non-purulent } \\
\text { - Mild photophobia and crusting upon } \\
\text { awakening may occur }\end{array}$ & $\begin{array}{l}\text { - History of atopy, seasonal allergy or } \\
\text { specific allergy is usually present in these } \\
\text { patients. } \\
\text { - All patients should be asked about a } \\
\text { previous history of similar symptoms. }\end{array}$ & $\begin{array}{l}\text { - Conjunctival hyperaemia } \\
\text { - Tearing and clear watery discharge } \\
\text { - Conjunctival oedema } \\
\text { - Injection (redness) in allergic conjunctivitis } \\
\text { is usually diffuse and involves the bulbar } \\
\text { conjunctiva as well as the palpebral and tarsal } \\
\text { conjunctiva } \\
\text { - On eyelid eversion: conjunctival papillae may be } \\
\text { present. } \\
\text { - Papillae vary in size from tiny red dots to } \\
\text { polygonal elevations } 1 \text { mm or more in diameter } \\
\text { - Papillae are usually found on the tarsal } \\
\text { conjunctiva } \\
\text { - Cobblestoning and large papillae are usually } \\
\text { indicative of other severe ocular allergic } \\
\text { disorders } \\
\text { - Patients with allergic rhinitis may also present } \\
\text { with: } \\
\text { - Allergic shiners } \\
\text { - Dennie-morgan lines } \\
\text { - A pale hue to the nasal mucosa } \\
\text { - Oedema of the nasal turbinates } \\
\text { - Clear rhinorrhoea maybe visible } \\
\text { - If the nasal passages are obstructed, there } \\
\text { may be clear dripping in the posterior } \\
\text { pharynx }\end{array}$ \\
\hline
\end{tabular}

\section{Clinical Presentation}

The prominent symptom of allergic conjunctivitis is ocular pruritis. ${ }^{1,17,18}$ The absence of pruritus should prompt the healthcare practitioner to consider other ocular disorders, for example bacterial, viral, fungal, autoimmune, and drug-induced conjunctivitis. Table 2 describes the clinical presentation of allergic rhinitis in terms of symptoms, clinical history and physical examination findings. ${ }^{1,17-19}$

\section{Diagnosis}

The diagnosis of this condition is primarily clinical and based on suggestive signs and symptoms consistent with allergic rhinitis. ${ }^{1}$ Laboratory testing is not required in order to initiate therapy, however, testing for allergy to specific substances should be pursued if the patient does not respond to treatment or in advanced conditions. ${ }^{1}$ In such situations it would be preferable to refer to an ophthalmologist. 1,19, 20

\section{Differential Diagnosis}

The differential diagnosis for this condition includes: infective conjunctivitis, more severe forms of ocular allergic diseases, blepharitis, drug-induced conjunctivitis, and keratoconjunctivitis sicca. Table 3 illustrates the different features of these conditions useful for differentiation.

\section{Management of Allergic Conjunctivitis}

The management of allergic conjunctivitis should include both non-pharmacological or pharmacological measures.

\section{Non-pharmacological measures}

Basic eye-care should be advised for these patients: ${ }^{17-21}$

1. Patients should not rub their eyes because rubbing can cause mechanical mast cell degranulation and worsening of symptoms.

2. Cool compresses can help reduce eyelid and periorbital oedema. 
Table 3: Differential diagnosis and feature of these conditions ${ }^{1,17,20}$

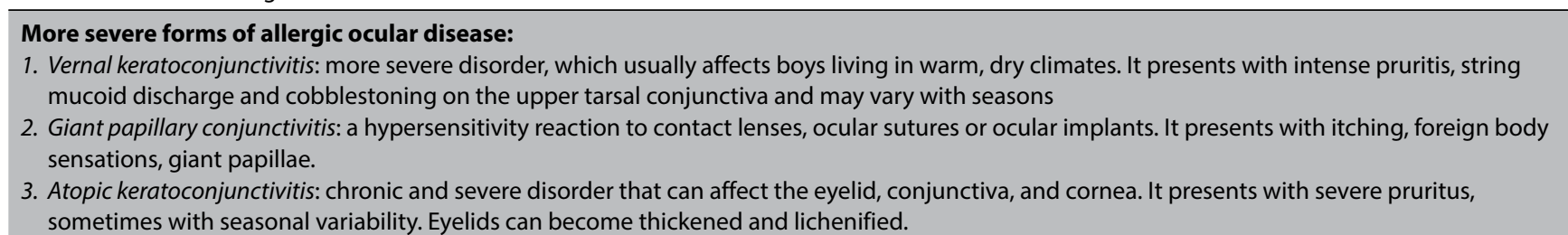

\section{Viral Infections}

Allergic conjunctivitis is often accompanied by significant ocular pruritus, however this is not the case with infectious eye conditions. Infection is usually unilateral, although it can be bilateral, whereas allergic conjunctivitis is usually bilateral.

\section{Bacterial Infections}

Produce some degree of purulent discharge and are unlikely to be mistaken for allergic conjunctivitis, but viral infections can present more subtly.

\section{Keratoconjunctivitis Sicca}

Allergic conjunctivitis principally affects the conjunctiva, whereas the principal target tissue in keratoconjunctivitis sicca is the cornea.

\section{Blepharitis \\ This principally affects the eyelids or lid margins whereas allergic conjunctivitis affects the conjunctiva. Eyelid involvement is characterised by vascularisation of lids, changes in meibomian glands, and presence of lid dander.}

\section{Angle Closure Glaucoma}

Allergic conjunctivitis is usually bilateral, and generally not associated with vision loss or ocular pain. Angle closure glaucoma is usually associated with unilateral ocular pain, vision loss and corneal oedema. Both allergic conjunctivitis and angle closure glaucoma do present with redness.

\section{Episcleritis/scleritis \\ Both scleritis and episcleritis are associated with significant pain but the pain of episcleritis may be delayed.}

\section{Drug-induced conjunctivitis}

Drug-induced cicatrising conjunctivitis is type of ocular toxicity resulting from different chemicals used as preservatives in eye drops. Preservatives like benzalkonium chloride (BAC) and related ammonium salts have been shown to play an important part as allergens in some patients. Other ophthalmic medications, for example antimicrobial, antifungal, antiviral, corticosteroid drops may also trigger hypersensitivity reactions in some patients especially in the first few days of use.

\section{Frequent use of refrigerated artificial tears throughout the day can help dilute and remove allergens.}

4. Patients should reduce or stop the use of contact lenses during their symptomatic periods.

Allergen avoidance or reduction of contact with known allergens is critical for effective management of allergic conjunctivitis, especially in more severe cases. ${ }^{17-21}$ Different advice should be given on the type of allergic conjunctivitis. This includes ${ }^{17-21}$ :

1. For SAC, patients should be advised to use air conditioning where possible. They should also be advised to limit outdoor exposure, and keep car and home windows closed during the peak pollen seasons.

2. For PAC, patients should be advised to avoid specific allergens that are the cause of the symptoms in a specific patient. For example: in patients allergic to dust mites, advice should be given to replace old pillow cases, blankets and mattresses or using dust mite allergen impermeable covers.

\section{Pharmacological Measures}

The mainstay of therapy for ocular related allergies included the use of allergic therapeutic treatments such as: antihistamine, multiple action anti-allergic agents and mast cell stabilizers. ${ }^{17}$

\section{Topical Treatments}

\section{Vasoconstrictor/antihistamine combinations (tetryzoline/ antazoline)}

These medicines are available as over the counter medicine with tetryzoline having a similar action to that of naphazoline. ${ }^{22}$ Tetryzoline, a topical vasoconstrictor, was indicated for ocular redness and continuous use would result in rebound hyperaemia. ${ }^{22,23}$ Antazoline is an antihistamine indicated topically for the symptomatic relief of allergic conjunctivitis. ${ }^{22}$ Antazoline may be useful in the case of histamine-induced itching. Antazoline has local stinging properties and may cause minor ocular irritation. ${ }^{22}$ Patients should be advised that increased eye redness for several days may result when the combination of tetryzoline/antazoline is stopped. ${ }^{22}$

\section{Antihistamines with mast cell stabilising properties (e.g.} olaptadine, ketotifen, emedastine, epinastine, ketotifen, etc.)

These drugs have two main mechanisms of action. They block histamine receptors in the conjunctiva and thus inhibit the action of this mediator. ${ }^{22,}{ }^{24}$ Furthermore, they stabilise mast cells and inhibit mast cell degranulation which in turn limits the release of histamine, tryptase and prostaglandin $D_{2}{ }^{22,25}$ They also inhibit leukocyte activity and dampen mediator release from basophils, eosinophils and neutrophils. ${ }^{22,25}$ Almost all these drugs are dosed twice daily, ${ }^{22}$ but two weeks of therapy should be allowed in order for the drugs to reach maximal efficacy as a prophylactic agent. Common adverse effects to expect with use are burning, stinging and irritation upon installation as well as headaches or ocular dryness. Patients may consider refrigerating the drops prior to use to combat these adverse effects or even consider the use of artificial tears with these medications. A systematic review and a Cochrane meta-analysis on the use of topical antihistamines have demonstrated their effectiveness in the management of both SAC and PAC. ${ }^{18,26}$

\section{Mast Cell Stabilisers (sodium cromoglycate, lodoxamide)}

The drugs stabilise mast cells and prevent the release of histamine. The maximal efficacy of these drugs is only reached 
between 5-14 days after initiation and thus cannot be used in the management of acute allergic conjunctivitis. ${ }^{27}$ The dosing of these drugs is more frequent than topical antihistamine and must be dosed four times daily. ${ }^{22,27}$ For this reason, it should be reserved as treatment for SAC in patients who cannot tolerate other therapy. A randomised trial which compared the use of cromolyn sodium (4 percent, four times daily) for two weeks prior to allergen challenge with a single drop of ketotifen fumarate (0.025 percent) given just before allergen challenge, found that the single drop of ketotifen was superior in controlling itching and redness at 15 minutes and at 4 hours after challenge. ${ }^{28}$ An analysis of the economic costs of olaptadine or sodium cromoglycate concluded that the more expensive olaptadine resulted in sufficiently fewer return visits than the most cost effective option of sodium cromoglycate. ${ }^{29}$

\section{Glucorticosteroids (loteprednol, flurometholone)}

These drugs should be considered in patients with refractory symptoms and should be prescribed by an ophthalmologist. Due to their adverse effect profile (cataract formation, increased intraocular pressure, glaucoma and secondary infections), these drugs should only be used as "pulse therapy" for a maximum of two weeks and only in patients where topical antihistamines and mast cell stabilisers have been ineffective. ${ }^{22}$ Soft steroids (e.g. loteprednol, flurometholone) are preferred to dexamethasone or prednisolone (1\%) as pulse therapy, as they are associated with the lower risk of increased intraocular pressure. ${ }^{30}$

\section{Systemic Therapy}

\section{Oral antihistamines (cetirizine, loratadine, fexofenadine)}

Non-sedating antihistamines are histamine -1- receptor $(\mathrm{H} 1)$ antagonists and are dosed once daily. They may be useful in patients with rhinitis or pruritus. ${ }^{22}$ Randomised trials have shown that topical medications are more effective than oral therapies for ocular symptoms. Specifically, topical olopatadine was more effective than oral loratadine or fexofenadine, and topical ketotifen was more effective than oral desloratadine. ${ }^{31-33}$ Oral antihistamine can cause drying of the mucosal membranes and in some patients may cause dry eyes. 22,34

Table 4: Rational drugs use of the different therapeutic modalities for the different types of allergic rhinitis ${ }^{22-34}$

\begin{tabular}{lll}
\hline $\begin{array}{l}\text { Type of allergic } \\
\text { conjunctivitis }\end{array}$ & First line agent & Second line agent \\
\hline $\begin{array}{l}\text { Acute Allergic } \\
\text { Conjunctivitis }\end{array}$ & $\begin{array}{l}\text { Considered a self-limiting } \\
\text { condition } \\
\text { Consider the use of } \\
\text { topical vasoconstrictor/ } \\
\text { antihistamine preparation for } \\
\text { two weeks }\end{array}$ & $\begin{array}{l}\text { Topical antihistamine } \\
\text { with mast cell stabilising } \\
\text { properties }\end{array}$ \\
& $\begin{array}{l}\text { Topical antihistamine } \\
\text { with mast cell stabilising } \\
\text { properties twice daily } \\
\text { Drugs should be initiated } \\
\text { two to four weeks prior } \\
\text { to anticipated onset of } \\
\text { symptoms }\end{array}$ & $\begin{array}{l}\text { Topical mast cell } \\
\text { stabilisers four times } \\
\text { daily }\end{array}$ \\
& $\begin{array}{l}\text { Topical antihistamine } \\
\text { with mast cell stabilising } \\
\text { properties twice daily }\end{array}$ & $\begin{array}{l}\text { Topical mast cell } \\
\text { stabilisers four times } \\
\text { daily }\end{array}$ \\
\hline PAC &
\end{tabular}

\section{Treatment for specific types of allergic conjunctivitis}

Rational drug selection of the different therapeutic modalities for the different types of allergic rhinitis is detailed in Table 4.

\section{Conclusion}

Allergic conjunctivitis is a condition characterised by conjunctival inflammation that may be acute, intermittent or chronic. There are three types of allergic conjunctivitis: acute allergic conjunctivitis, SAC and PAC. The prominent symptom of allergic conjunctivitis is ocular pruritis. Drug therapy should be confined to topical treatments with topical antihistamine with mast cell stabilising properties being the drug of choice for SAC and PAC, while the use of topical vasoconstrictor/antihistamine should be considered for acute allergic conjunctivitis.

\section{References:}

1. Roat, MI. Allergic Conjuncitivis. The Merck Manual Online professional version.2016 [accessed August 2017]. Available from: http://www.msdmanuals. $\mathrm{com} / \mathrm{professional/eye-disorders/conjunctival-and-scleral-disorders/}$ allergic-conjunctivitis)

2. Singh $\mathrm{K}$, Axelrod $\mathrm{S}$, Bielory $\mathrm{L}$. The epidemiology of ocular and nasal allergy in the United States, 1988-1994. J Allergy Clin Immunol. 2010;126:778.

3. Wang $H Y$, Pizzichini MM, Becker $A B$, et al. Disparate geographic prevalences of asthma, allergic rhinoconjunctivitis and atopic eczema among adolescents in five Canadian cities. Pediatr Allergy Immunol. 2010;21:867.

4. Kusunoki T, Morimoto T, Nishikomori R, et al. Changing prevalence and severity of childhood allergic diseases in Kyoto, Japan, from 1996 to 2006. Allergol Int. 2009;58:543.

5. Rosario N, Bielory L. Epidemiology of allergic conjunctivitis. Curr Opin Allergy Clin Immunol. 2011;11:471.

6. Bousquet J, Khaltaev N, Cruz AA, et al. Allergic Rhinitis and its Impact on Asthma (ARIA) 2008 update (in collaboration with the World Health Organization, GA(2) LEN and AllerGen). Allergy. 2008;63(86)Suppl:8.

7. Tsubota K, Takamura E, Hasegawa T, Kobayashi T. Detection by brush cytology of mast cells and eosinophils in allergic and vernal conjunctivitis. Cornea. 1991;10:525.

8. Ehlers WH, Donshik PC. Allergic ocular disorders: a spectrum of diseases. CLAO J. 1992;18:117.

9. Bonini $\mathrm{S}$, Bonini $\mathrm{S}$, Berruto $\mathrm{A}$, et al. Conjunctival provocation test as a model for the study of allergy and inflammation in humans. Int Arch Allergy Appl Immunol 1989;88:144

10. Cohan VL, Massey WA, Gittlin SD, et al. The heterogeneity of human histamine containing cells. In: Mast cell and basophil differentiation and function in health and disease. Galli SJ, Austen KF (Eds). Raven Press, New York 1989.

11. Bonini $S$, Centofanti $M$, Schiavone $M$, et al. The pattern of the ocular late phase reaction induced by allergen challenge in hay fever conjunctivitis. Ocul Immunol Inflamm. 1994;2:191.

12. Abelson MB, Madiwale $\mathrm{N}$, Weston JH. Conjunctival eosinophils in allergic ocular disease. Arch Ophthalmol. 1983;101:555.

13. Bonini S, Centofanti M, Schiavone M. Passive transfer of the ocular late-phase reaction. Ocul Immunol Inflamm. 1993;4:323.

14. Abelson MB, Udell IJ, Weston JH. Conjunctival eosinophils in compound $48 / 80$ rabbit model. Arch Ophthalmol. 1983;101:631.

15. Rodier F, Gautrin D, Ghezzo H, Malo JL. Incidence of occupational rhinoconjunctivitis and risk factors in animal-health apprentices. J Allergy Clin Immunol. 2003;112:1105.

16. Ono SJ, Abelson MB. Allergic conjunctivitis: update on pathophysiology and prospects for future treatment. J Allergy Clin Immunol. 2005;115:118.

17. La Rosa M, Lionetti $E$, Reibaldi $M$, et al. Allergic conjunctivitis: a comprehensive review of the literature. Ital J Pediatr. 2013;39:18. doi: 10.1186/1824-7288-39-18.

18. Owen CG, Shah A, Henshaw K, Smeeth L, Sheikh A. Topical treatments for seasonal allergic conjunctivitis: systematic review and meta-analysis of efficacy and effectiveness. Br J Gen Pract.2004;54(503):451-6.

19. National Department of Health, South Africa. Allergic Conjunctivitis Management Guidelines 2015 [cited 30 August 2017]. Adapted from: Standard 
Treatment Guidelines and Essential Drugs List PHC (2014) Available from: http:// www.kznhealth.gov.za/pharmacy/edlphc2014a.pdf

20. Dipiro JT, Talbert RL, Yee GC, Matzke GR, Well BG, Posey LM, eds. Pharmacotherapy A pathophysiologic approach. $9^{\text {th }}$ ed. New York: McGraw-Hill; 2014

21. Bilkhu PS, Wolffsohn JS, Naroo SA, et al. Effectiveness of nonpharmacologic treatments for acute seasonal allergic conjunctivitis. Ophthalmology. 2014;121:72.

22. Rossiter D, Blockman M, Barnes Kl, Cohen K, Decloedt E, Irhuma M, Maartens G, Pandie M, Sinxadi PZ, et al. eds. South African Medicines Formulary. $12^{\text {th }}$ Edition. Cape Town: South African Medical Association Health and Publishing Group;2016.

23. Spector SL, Raizman MB. Conjunctivitis medicamentosa. J Allergy Clin Immunol. 1994;94:134.

24. Stiehm ER, Ochs HD, Winkelstein JA. Immunodeficiency disorders: General considerations. In: Immunologic disorders in infants and children. Stiehm ER, Ochs HD, Winkelstein JA (Eds). Elsevier Saunders, Philadelphia 2004. p.423.

25. Berdy GJ, Smith LM, George MA. The effects of disodium cromoglycate in the human model of acute allergic conjunctivitis. Invest Ophthalmol Vis Sci. 1989;30 Suppl:503.

26. Castillo M, Scott NW, Mustafa MZ, Mustafa MS, Azuara-Blanco A. Topical antihistamines and mast cell stabilisers for treating seasonal and perennial allergic conjunctivitis. Cochrane Database Syst Rev. 1 Jun 2015;(6):CD009566. doi:10.1002/14651858.CD009566.pub2.Review

27. Nizami RM. Treatment of ragweed allergic conjunctivitis with $2 \%$ cromolyn solution in unit doses. Ann Allergy. 1981 47:5.
28. Greiner JV, Michaelson C, McWhirter CL, Shams NB. Single dose of ketotifen fumarate $.025 \%$ vs 2 weeks of cromolyn sodium $4 \%$ for allergic conjunctivitis. Adv Ther. 2002;19:185.

29. Guest JF, Clegg JP, Smith AF. Health economic impact of olopatadine compared to branded and generic sodium cromoglycate in the treatment of seasonal allergic conjunctivitis in the UK. Curr Med Res Opin. 2006;22:1777.

30. Druzgala P, Wu WM, Bodor N. Ocular absorption and distribution of loteprednol etabonate, a soft steroid, in rabbit eyes. Curr Eye Res. 1991;10:933.

31. Abelson MB, Welch DL. An evaluation of onset and duration of action of patanol (olopatadine hydrochloride ophthalmic solution $0.1 \%$ ) compared to Claritin (loratadine $10 \mathrm{mg}$ ) tablets in acute allergic conjunctivitis in the conjunctival allergen challenge model. Acta Ophthalmol Scand Suppl. 2000;60.

32. Spangler DL, Abelson MB, Ober A, Gotnes PJ. Randomized, double-masked comparison of olopatadine ophthalmic solution, mometasone furoate monohydrate nasal spray, and fexofenadine hydrochloride tablets using the conjunctival and nasal allergen challenge models. Clin Ther. 2003;25:2245.

33. Crampton HJ. Comparison of ketotifen fumarate ophthalmic solution alone, desloratadine alone, and their combination for inhibition of the signs and symptoms of seasonal allergic rhinoconjunctivitis in the conjunctival allergen challenge model: a double-masked, placebo- and active-controlled trial. Clin Ther. 2003;25:1975.

34. Ousler GW 3rd, Workman DA, Torkildsen GL. An open-label, investigator-masked crossover study of the ocular drying effects of two antihistamines, topical epinastine and systemic loratadine, in adult volunteers with seasonal allergic conjunctivitis. Clin Ther. 2007;29:611. 